\title{
Support Vector Machine Untuk Klasifikasi Citra Jenis Daging Berdasarkan Tekstur Menggunakan Ekstraksi Ciri Gray Level Co-Occurrence Matrices (GLCM)
}

\author{
Neneng ${ }^{\mathrm{a}^{*}}$, Kusworo Adi ${ }^{\mathrm{b}}$, R. Rizal Isnanto ${ }^{\mathrm{c}}$ \\ ${ }^{a}$ STMIK Teknokrat Bandar Lampung \\ ${ }^{\mathrm{b}}$ Fakultas Sains dan Matematika Universitas Diponegoro \\ c Fakultas Teknik Universitas Diponegoro
}

Naskah Diterima : 14 Januari 2016; Diterima Publikasi : 15 Maret 2016

DOI: $10.21456 /$ vol6iss1pp1-10

\begin{abstract}
Texture is one of the most important features for image analysis, which provides informations such as the composition of texture on the surface structure, changes of the intensity, or brightness. Gray level co-occurence matrix (GLCM) is a method that can be used for statistical texture analysis. GLCM has proven to be the most powerful texture descriptors used in image analysis. This study uses the four-way GLCM $0^{\circ}, 45^{\circ}, 90^{\circ}$, and $135^{\circ}$. Support vector machine (SVM) is a machine learning that can be used for image classification. SVM has a high generalization capability without any requirement of additional knowledge, even with the high dimension of the input space. The data used in this study are the image of goat meat, buffalo meat, horse meat, and beef with shooting distance $20 \mathrm{~cm}, 30 \mathrm{~cm}$ and $40 \mathrm{~cm}$. The result of this study shows that the best recognition rate of $87.5 \%$ was taken at a distance of $20 \mathrm{~cm}$ with neighboring pixels distance $\mathrm{d}=2$ in the direction GLCM $135^{\circ}$.
\end{abstract}

Keywords : Image; GLCM; Tecture; SVM

\begin{abstract}
Abstrak
Tekstur merupakan salah satu ciri yang paling penting untuk analisis citra, dimana tekstur menyediakan informasi mengenai susunan stuktur pada permukaan, perubahan intensitas, atau kecerahan warna. Grey level co-occurence matrix (GLCM) merupakan metode yang dapat digunakan untuk analisis tekstur statistik. GLCM telah terbukti menjadi deskriptor tekstur yang paling kuat yang digunakan dalam analisis citra. Penelitian ini menggunakan empat arah GLCM yakni $0^{\circ}, 45^{\circ}, 90^{\circ}$, dan $135^{\circ}$. Support vector machine (SVM) merupakan mesin pembelajaran yang dapat digunakan untuk klasifikasi citra. SVM memiliki kemampuan generalisasi yang tinggi tanpa persyaratan pengetahuan tambahan, bahkan dengan dimensi yang tinggi dari ruang input. Data yang digunakan dalam penelitian ini adalah citra daging kambing, daging kerbau, daging kuda, dan daging sapi dengan jarak pengambilan $20 \mathrm{~cm}, 30 \mathrm{~cm}$, dan $40 \mathrm{~cm}$. Penelitian ini menghasilkan tingkat pengenalan terbaik yakni $87,5 \%$ berada pada jarak pengambilan $20 \mathrm{~cm}$ dengan jarak piksel tetangga $\mathrm{d}=2$ pada arah GLCM $135^{\circ}$.
\end{abstract}

Kata kunci : Citra; GLCM; Tekstur; SVM

\section{Pendahuluan}

Tekstur merupakan pola atau karakteristik yang teratur maupun acak pada sebuah objek atau gambar (Schwartz dan Pedrini, 2006). Tekstur adalah salah satu ciri yang paling penting untuk analisis citra, dimana tekstur menyediakan informasi mengenai susunan stuktur pada permukaan, perubahan intensitas, atau kecerahan warna (Siqueira et al., 2013). Ciri tekstur dapat digolongkan menjadi empat jenis, yakni tekstur statistik, tekstur struktur, tekstur berbasis model, dan tekstur berbasis transformasi.

*) Penulis korespondensi: neneng060880@yahoo.co.id
Diantara empat jenis tekstur tersebut, tekstur statistik yang paling banyak digunakan dalam industri makanan untuk melakukan penilaian kualitas maupun klasifikasi (Bharati et al., 2004).

Metode yang dapat digunakan untuk analisis tekstur statistik diantaranya adalah grey level cooccurence matrix (GLCM), grey level pixel-run length matrix, dan neighbouring grey level dependence matrix (Zheng et al., 2006). Diantara metode tersebut, GLCM yang paling banyak digunakan di mana ciri tekstur diekstraksi dengan beberapa pendekatan statistik dari matriks co- 
occurrence (Haralick et al., 1973). GLCM telah terbukti menjadi deskriptor tekstur yang paling kuat yang digunakan dalam analisis citra (Siqueira et al., 2013).

Dalam proses analisis tekstur, perhitungan ciri dibutuhkan untuk setiap tekstur dimana ciri-ciri ini mengandung informasi karakteristik yang dapat di gambarkan secara visual maupun tidak (Basset et al., 2000). Seleksi ciri dalam klasifikasi memiliki tiga tujuan yaitu: (1) untuk mengurangi biaya penggalian ciri, (2) untuk meningkatkan akurasi klasifikasi, dan (3) untuk meningkatkan keandalan estimasi kinerja (Kudo dan Sklansky, 2000).

Penelitian ilmiah tentang tekstur masih terbatas karena keragaman pola tekstur, sehingga penelitian tentang tekstur gambar menjadi lebih sulit dan sejauh ini belum ada metode karakterisasi tekstur ideal yang tersedia (Patel, Davies, dan Hannah, 1996). Namun demikian, beberapa ide tentang bagaimana tekstur dapat dikembangkan dibagi dalam dua aspek yang berbeda. Pertama, tekstur umumnya disebut sebagai ketergantungan antara piksel dan piksel tetangga dalam gambar. Kedua, tekstur didefinisikan sebagai variasi dari nilai intensitas di seluruh piksel (Haralick, 1979).

Terdapat beberapa mesin pembelajaran untuk klasifikasi citra, seperti jaringan syaraf tiruan, logika fuzzy, algoritma genetika, dan support vector machine (SVM). Struktur dari jaringan syaraf tiruan sulit untuk memahami dan menangkap atribut yang unik dalam tahap pelatihan. Logika fuzzy memerlukan pengetahuan sebelumnya tentang sistem, sedangkan algoritma genetika memiliki komplikasi pada tahap pelatihan atau output data (Seetha et al., 2008). Dari berbagai mesin pembelajaran yang tersedia tersebut, SVM memiliki kemampuan generalisasi yang tinggi tanpa persyaratan pengetahuan tambahan, bahkan dengan dimensi yang tinggi dari ruang input (Burges, 1998). SVM merupakan teknik yang sangat berguna untuk klasifikasi data dan masalah regresi yang diciptakan oleh Vladimir Vapnik (Salat dan Osowski, 2004).

\section{Kerangka Teori}

\subsection{Pengolahan Citra dan Analisis Citra}

Pengolahan citra dan analisis citra merupakan inti dari visi komputer (Krutz et al., 2000). Pengolahan citra/analisis mencakup serangkaian langkah yang secara garis besar dibagi menjadi tiga tingkatan yaitu pengolahan tingkat rendah, pengolahan tingkat menengah, dan pengolahan tingkat tinggi yang ditunjukkan pada Gambar 1 (Sun, 2000).

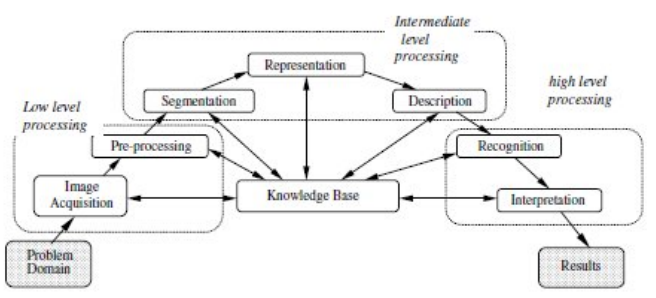

Gambar 1. Tingkatan Proses Pengolahan Citra (Sun, 2000)

\subsection{Jenis Citra}

Dalam pemrosesan citra, terdapat tiga jenis citra yang umum digunakan yakni citra berwarna, citra berskala keabuan, dan citra biner yang dijelaskan sebagai berikut (Kadir dan Susanto, 2013):

1. Citra berwarna

Citra berwarna atau yang sering disebut citra RGB adalah jenis citra yang menyajikan warna dalam bentuk komponen R (merah), G (hijau), dan B (biru). Setiap komponen warna tersebut menggunakan delapan bit yang nilainya berkisar antara 0 sampai dengan 255. Dengan demikian, komponen warna yang dapat disajikan mencapai 16.581.375 warna. Tabel 1 berikut menjelaskan contoh warna dan nilai RGB-nya.

Tabel 1. Warna dan nilai penyusun warna

\begin{tabular}{lccc}
\hline \multicolumn{1}{c}{ Warna } & R & G & B \\
\hline Merah & 255 & 0 & 0 \\
Hijau & 0 & 255 & 0 \\
Biru & 0 & 0 & 255 \\
Hitam & 0 & 0 & 0 \\
Putih & 255 & 255 & 255 \\
Kuning & 0 & 255 & 255 \\
\hline
\end{tabular}

2. Citra berskala keabuan

Citra jenis ini menangani gradasi warna hitam dan putih yang menghasilkan efek warna abuabu. Pada jenis gambar ini, warna dinyatakan dengan intensitas yang berkisar antara 0 sampai dengan 255. Nilai 0 menyatakan hitam, sedangkan nilai 255 menyatakan putih.

3. Citra biner

Citra biner merupakan citra yang setiap pikselnya hanya dinyatakan dengan nilai dari dua kemungkinan yakni nilai 0 dan 1 . Nilai 0 menyatakan warna hitam, sedangkan nilai 1 menyatakan warna putih.

Dalam prakteknya, mengingat banyak pemrosesan yang bekerja pada skala keabuan, maka citra berwarna seringkali harus dikonversi terlebih dahulu ke dalam bentuk citra berskala keabuan. Untuk mengubah citra RGB menjadi citra skala keabuan dapat dilakukan dengan rumus sebagai berikut:

Skala keabuan $=0.299 R+0.587 G+0.144 B$

atau

Skala keabuan $=0.333 R+0.333 G+0.333 B$ 


\subsection{GLCM}

Kulkarni (1994) dalam Kadir dan Susanto (2013) mengatakan bahwa GLCM pertama kali diusulkan oleh Haralick pada tahun 1973 dengan 28 fitur untuk menjelaskan pola spasial. Hall-Bayer (2007) dalam Kadir dan Susanto (2013) menjelaskan GLCM menggunakan perhitungan tekstur pada orde kedua. Pada orde pertama, pengukuran tekstur menggunakan perhitungan statistik didasarkan pada nilai piksel citra asli semata, seperti varians, dan tidak memperhatikan hubungan ketetanggaan piksel. Sedangkan hubungan antar pasangan dua piksel citra asli diperhitungkan pada orde kedua.

Misalkan, $\mathrm{f}(\mathrm{x}, \mathrm{y})$ adalah citra dengan ukuran $\mathrm{Nx}$ dan Ny yang memiliki piksel dengan kemungkinan hingga $\mathrm{L}$ level dan $\vec{r}$ adalah vektor arah ofset spasial. $G L C M_{\vec{r}}(i, j)$ didefinisikan sebagai jumlah piksel dengan $j \in 1, \ldots, L$ yang terjadi pada offset $\vec{r}$ terhadap piksel dengan nilai $j \in 1, \ldots, L$, yang dapat dinyatakan dalam rumus sebagai berikut (Newsam dan Kammath, 2005 dalam Kadir dan Susanto, 2012).

$$
\begin{aligned}
& \operatorname{GLCM}_{r}\left(i_{i}\right)=\#\left\{\left(x_{1}, y_{1}\right)\left(x_{2}, y_{2}\right) \in\left(N_{x} N_{y}\right) \times\left(N_{n}, N_{y}\right) f\left(x_{1} y_{1}\right)=j^{r}=\right. \\
& \overline{\left.\left(x_{2}-x_{1}\right)_{2}-y_{1}\right)}
\end{aligned}
$$

Dalam hal ini, ofset $\overrightarrow{r^{\prime}}$ dapat berupa sudut dan/atau jarak. Gambar 2 berikut memperlihatkan empat arah untuk GLCM (Kadir dan Susanto, 2012).

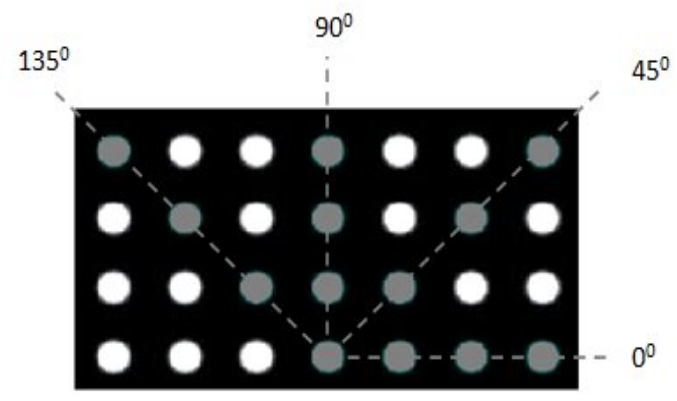

Gambar 2. Contoh arah untuk GLCM

dengan sudut $0^{\circ}, 45^{\circ}, 90^{\circ}$, dan $135^{\circ}$ (Kadir dan Susanto, 2012)

Untuk kepentingan ilustrasi, ketetanggaan piksel dapat dipilih ke arah timur (kanan). Salah satu cara untuk merepresentasikan hubungan ini yaitu berupa $(1,0)$, yang menyatakan hubungan dua piksel yang berjajar horizontal dengan piksel bernilai 1 diikuti dengan piksel bernilai 0. Berdasarkan komposisi tersebut, jumlah kelompok piksel yang memenuhi hubungan tersebut dihitung. Hal ini diilustrasikan pada Gambar 3 sebagai berikut (Kadir dan Susanto, 2012).
Gambar 3. Penentuan awal matriks GLCM berbasis pasangan dua piksel (Kadir dan Susanto, 2012)

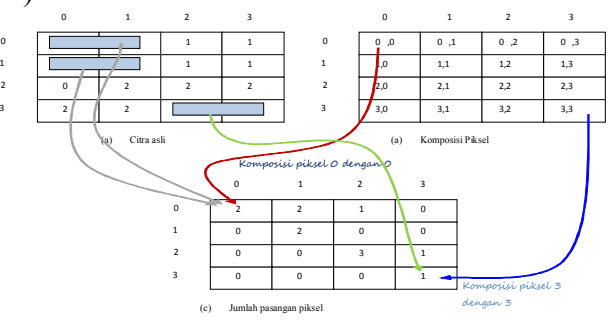

Gambar 3. Penentuan awal matriks GLCM berbasis pasangan dua piksel (Kadir dan Susanto, 2012)

Matriks pada Gambar 2.3 disebut dengan matriks framework. Matriks ini perlu diolah menjadi matriks yang simetris dengan cara menambahkan dengan hasil transposnya, sebagaimana diperlihatkan pada Gambar 4 (Kadir dan Susanto, 2012).

$$
\begin{aligned}
& {\left[\begin{array}{llll}
2 & 2 & 1 & 0 \\
0 & 2 & 0 & 0 \\
0 & 0 & 3 & 1 \\
0 & 0 & 0 & 1
\end{array}\right]+\left[\begin{array}{llll}
2 & 0 & 0 & 0 \\
2 & 2 & 0 & 0 \\
1 & 0 & 3 & 0 \\
0 & 0 & 0 & 1
\end{array}\right]=\left[\begin{array}{llll}
4 & 2 & 1 & 0 \\
2 & 4 & 0 & 0 \\
1 & 0 & 6 & 1 \\
0 & 0 & 1 & 2
\end{array}\right]} \\
& \begin{array}{l}
\text { GLCM sebelum } \\
\text { Transpos }
\end{array}
\end{aligned}
$$

Gambar 4. Contoh pembentukan matriks GLCM yang simetris (Kadir dan Susanto, 2012)

Nilai-nilai elemen GLCM perlu dinormalisasi sehingga jumlahnya bernilai 1 untuk menghilangkan ketergantungan pada ukuran citra. Dengan demikian, contoh di atas menjadi seperti berikut (Kadir dan Susanto, 2012).

$$
\left[\begin{array}{cccc}
\frac{4}{24} & \frac{2}{24} & \frac{1}{24} & \frac{0}{24} \\
\frac{2}{24} & \frac{4}{24} & \frac{0}{24} & \frac{0}{24} \\
\frac{1}{24} & \frac{0}{24} & \frac{6}{24} & \frac{1}{24} \\
\frac{0}{74} & \frac{0}{24} & \frac{1}{74} & \frac{2}{24}
\end{array}\right]
$$

Hanya beberapa besaran yang diusulkan Haralick yang dipakai untuk mendapatkan fitur GLCM. Sebagai contoh, Newsam dan Kammath (2005) hanya menggunakan lima besaran untuk GLCM yakni angular second moment (ASM), contras, inverse different moment (IDM), entropi, dan korelasi (Kadir dan Susanto, 2013). 
ASM merupakan ukuran homogenitas citra dihitung dengan cara sebagai berikut:

$$
A S M-\sum_{i=1}^{2} \sum_{j=1}^{2}(G L C M(b))^{2}
$$

Dalam hal ini, $L$ menyatakan jumlah level yang digunakan untuk komputasi.

Kontras merupakan ukuran keberadaan variasi atas keabuan piksel citra, dihitung dengan cara sebagai berikut:

$$
\text { Kontras }=\sum_{n=1}^{\infty} n^{2}\left\{\sum_{1:} \operatorname{GLCN}(i, j)\right\}
$$

IDM digunakan untuk mengukur homogenitas, dihitung dengan cara sebagai berikut:

$$
W n=\sum_{i=1}^{2} \sum_{j=1}^{2} \frac{\left(G L C M(i, n)^{2}\right.}{1+(i-j)^{2}}
$$

Entropi menyatakan ukuran ketidakteraturan aras keabuan di dalam citra. Nilainya tiggi jika elemenelemen GLCM mempunyai nilai yang relatif sama. Nilai rendah jika elemen-elemen GLCM dekat dengan nilai 0 atau 1 . Rumus untuk menghitung entropi adalah sebagai berikut:

$$
\text { Entropi }=\sum_{i=1}^{2} \sum_{j=1}^{2}(\operatorname{GLCM}(i, j) \log (\operatorname{GLCM}(i, j)
$$

Korelasi yang merupakan ukuran ketergantungan linear antar nilai aras keabuan dalam citra dihitung menggunakan rumus sebagai berikut:

$$
\begin{aligned}
& \text { dengan } \\
& \mu_{i}=\sum_{i=1}^{2} \sum_{j=1}^{2} i^{*} \operatorname{GLCM}(i, j) \\
& \mu_{j}^{\prime}=\sum_{i=1}^{2} \sum_{j=1}^{2} j^{*} \operatorname{GLCM}(i, j) \\
& \sigma_{f}^{2}=\sum_{i=1}^{2} \sum_{j=1}^{2} \operatorname{GLCM}(i, j)\left(i-\mu_{i}\right)^{2} \\
& \sigma_{i}^{2}=\sum_{i=1}^{2} \sum_{j=1}^{2} \operatorname{GLCM}(i, j)\left(i-\mu_{i}^{2}\right)^{2}
\end{aligned}
$$$$
\text { Korelasi }=\sum_{i=1}^{2} \sum_{j=1}^{2} \frac{(i j)\left(G L C M(i, j) \mu_{i}^{n} \mu_{j}^{n}\right.}{\sigma_{i} \sigma_{j}}
$$

\subsection{Support Vector Machine}

SVM merupakan sistem pembelajaran yang menggunakan ruang hipotesis berupa fungsi-fungsi linier dalam sebuah ruang ciri (feature space) berdimensi tinggi, dilatih dengan algoritma pembelajaran yang didasarkan pada teori optimasi dengan mengimplementasikan bias pembelajaran yang berasal dari teori pembelajaran statistik (Nello dan Taylor, 2000).

SVM merupakan metode klasifikasi yang kini banyak dikembangkan dan diterapkan. Metode ini berasal dari teori pembelajaran statistik yang menjanjikan dan memberikan hasil yang lebih baik dibandingkan dengan metode yang lainnya. SVM bekerja sangat baik pada himpunan data berdimensi tinggi. SVM yang menggunakan teknik kernel harus memetakan data asli dari dimensi asalnya menjadi dimensi lain yang relatif lebih tinggi. Pada metode ANN, selama proses pelatihan semua data latih akan dipelajari. Berbeda dengan SVM yang hanya sejumlah data terpilih sajalah yang digunakan dalam klasifikasi yang akan dipelajari. Berbeda juga dengan Nearest Neighboar yang menyimpan semua data latih yang akan digunakan pada saat prediksi, SVM hanya menyimpan sebagian dzecil data latih untuk digunakan pada saat prediksı. Hal inilah yang menjadi kelebihan SVM kerena tidak semua data latih dilibatkan pada saat pelatihan (Prasetyo, 2014)

\subsection{Konsep $S V M$}

Ide dasar dari SVM adalah memaksimalkan batas hyperplane yang dijelaskan pada Gambar 5.
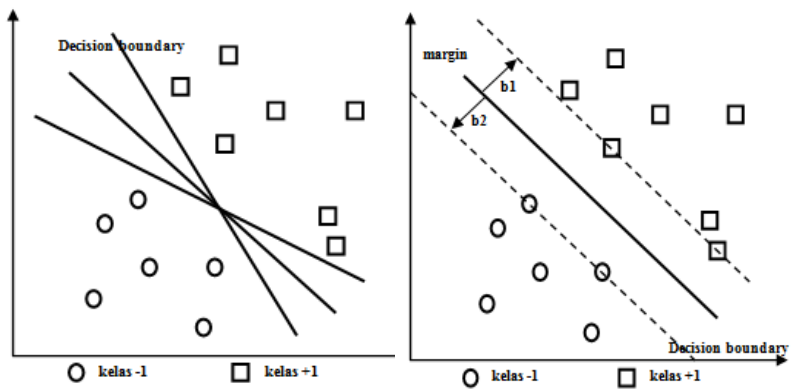

Gambar 5. Batas keputusan yang mungkin untuk set data (Prasetyo, 2014)

Nugroho (2007) dalam Eko Prasetyo (2014) menjelaskan konsep klasifikasi dengan SVM adalah sebagai usaha mencari hyperplane terbaik yang berfungsi sebagai pemisah dua buah kelas data pada input space. Pada gambar 2.5 memperlihatkan beberapa data yang merupakan anggota dari dua buah kelas data yakni +1 dan -1 . Bentuk lingkaran merupakan simbol data yang tergabung dalam kelas -1, sedangkan bentuk bujur sangkar merupakan simbol data yang tergabung dalam kelas +1 . Hyperplane pemisah terbaik antara kedua kelas tersebut dapat ditemukan dengan mengukur margin hyperplane dan mencari titik maksimalnya. Margin merupakan jarak antara hyperplane tersebut dengan data terdekat dari masing-masing kelas. Data yang paling dekat inilah yang disebut dengan support vector. Pada gambar $2 \mathrm{~b}$ di atas menunjukkan hyperplane terbaik karena terletak di tengah-tengah kedua kelas. Data lingkaran dan bujur sangkar yang 
dilewati garis putus-putus (garis batas margin) adalah support vector. Inti dari proses pelatihan pada SVM ini adalah usaha untuk mencari lokasi hyperplane (Prasetyo, 2014).

\subsection{Hyperplane SVM}

Secara matematika, formulasi problem optimasi SVM untuk kasus klasifikasi linear di dalam primal space adalah sebagai berikut (Prasetyo, 2012):

$$
\min \frac{1}{2}\|w\|^{2}
$$

Syarat

$$
y_{i}\left(w x_{i}+b\right) \geq 1, i=1, \ldots l
$$

Optimalisasi ini dapat diselesaikan dengan pengali Langrange:

$$
L_{p}-\frac{1}{2}\|w\|^{2}-\sum_{i=1}^{N} \alpha_{i} y_{i}\left(w x_{1}+b\right)-1
$$

$\alpha i$ adalah Langrange Multiplier yang berkorespondensi dengan $x i$. Nilai $\alpha i$ adalah nol atau positif. Untuk meminimalkan pengali Langrange, persamaan 14 harus diturunkan pada $w$ dan $b$, dan diset dengan nilai nol untuk syarat optimalisasi di atas.

Syarat 1:

$$
\frac{\partial L_{P}}{\partial_{w}}=0 \Rightarrow w=\sum_{i=1}^{N} \alpha_{i} y_{i} x_{1}
$$

Syarat 2:

$$
\frac{\partial L_{P}}{\partial_{2}}=0 \rightarrow W_{W}=\sum_{i=1}^{W} x_{i} y_{i}=0
$$

$\mathrm{N}$ adalah jumlah data yang menjadi support vector. Karena Langrange Multiplier $(\alpha)$ tidak diketahui nilainya, persamaan di atas tidak dapat diselesaikan secara langsung untuk mendapatkan $w$ dan $b$.

Untuk menyelesaikan masalah tersebut, persamaan 14 dimodifikasi menjadi kasus pemaksimalan, syarat optimal untuk dualitasnya menggunakan kendala (constraint) Karush Kuhn Tucker (KKT) berikut:

Syarat 1:

$$
u_{i}\left[y_{i}\left(w \cdot x_{i}+b\right)-1\right]=0
$$

Syarat 2:

$$
\alpha_{i} \geq 0, i=1,2 \ldots \mathrm{N}
$$

Dengan menerapkan kendala pada persamaan 17 dan 18, dipastikan bahwa nilai Langrange Multiplier sama banyaknya dengan data latih, tetapi sebenarnya banyak dari data latih yang Langrange Multiplier- nya sama dengan nol (karena hanya beberapa saja yang akan menjadi support vector) ketika menerapkan syarat pertama. Kendala di atas menyatakan bahwa Langrange $\alpha i$ harus nol, kecuali untuk data latih $x i$ yang memenuhi persamaan

$$
y_{i}\left(w \cdot x_{i}+b\right)=1
$$

Data latih itu dengan $\alpha i>$, terletak pada hyperplane $b_{i 1}$ atau $b_{i 2}$ dan disebut support vector. Data latih yang tidak terletak di hyperplane tersebut mempunyai $\alpha i=0$. Persamaan 17 dan 18 juga menyarankan parameter $w$ dan $b$, yang mendefinisikan hyperplane, hanya tergantung pada support vector. Walaupun bias diselesaikan, masalah optimalisasi di atas masih sulit karena banyaknya parameter: w, b, dan $\alpha i$. Untuk menyederhanakannya persamaan optimalisasi 14 harus ditransformasi ke dalam fungsi Langrange itu sendiri.

Persamaan Langrange Multiplier 13 dijabarkan menjadi

$$
L_{p}=\frac{1}{2}\|\boldsymbol{w}\|^{2}-\sum_{i=1}^{N} \alpha_{i} y_{i}\left(\boldsymbol{w}, \boldsymbol{x}_{i}\right)-b \sum_{i=1}^{N} \alpha_{i} y_{i}+\sum_{i=1}^{N} \alpha_{i}
$$

Syarat optimal 16 ada dalam suku ke tiga ri ruas kanan dalam persamaan 20, dan memaksa suku ini menjadi sama dengan 0. Dengan mengganti $w$ dari syarat $15,\left.\|d\|_{\|}\right|^{2} \mathrm{~s}=\boldsymbol{w}_{i}, \boldsymbol{w}_{j} \quad$ persamaan di atas akan berubah menjadi dualitas Langrange Multiplier yang berupa Ld, di dapatkan:

Maksimalkan:

$$
\mathrm{Ld}=\sum_{i=1}^{N} \alpha_{\mathrm{i}}-\frac{1}{2} \sum_{i j} \alpha_{\mathrm{i}} \alpha_{i} \mathrm{y}_{\mathrm{i}} \mathrm{y}_{\mathrm{j}} \mathbf{x}_{\mathrm{i}} \cdot \mathbf{x}_{\mathrm{j}}
$$

Syarat 1

$$
\sum_{i=1}^{N} \alpha_{i} y_{i}=0
$$

Syarat 2:

$$
\alpha i \geq 0, \mathrm{i}=1,2 \ldots . \mathrm{N}
$$

Xi. Xj merupakan dot-product dua data dalam data latih.

\subsection{SVM Non Linear}

Dalam SVM terdapat SVM linear dan SVM non linear (kernel trick). SVM sebenarnya hanya bekerja pada data yang dapat dipisahkan secara linear. Untuk data yang tidak linear dapat menggunakan metode kernel pada fitur data awal set data. Kernel adalah suatu fungsi yang memetakan fitur data dari dimensi rendah ke fitur baru dengan dimensi yang relatif lebih tinggi seperti diilustrasikan dalam gambar 6 (Prasetyo, 2014): 


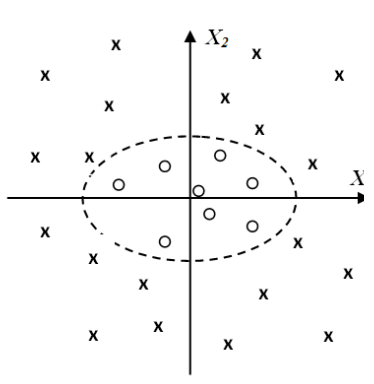

a. Data dalam fitur dimensi rendah

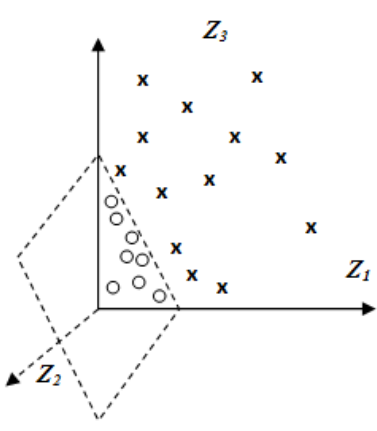

b. Data dalam fitur
dimensi tinggi
Gambar 6. Dimensi data (Prasetyo, 2014)

Algoritma pemetaan kernel dijelaskan sebagai berikut :

$$
\begin{gathered}
\Phi: D^{r} \rightarrow D^{q} \\
\mathrm{x} \rightarrow \Phi(\mathrm{x})
\end{gathered}
$$

$\Phi$ merupakan fungsi kernel yang digunakan untuk pemetaan, $D$ merupakan data latih, $r$ merupakan set fitur dalam satu data yang lama, $q$ merupakan set fitur yang baru sebagai hasil pemetaan untuk setiap data latih. Sementara $\mathrm{x}$ merupakan data latih, dengan $x_{1}, x_{2}, \ldots . x_{N} \in D^{r}$ merupakan fitur-fitur yang akan dipetakan ke fitur berdimensi tinggi $q$. Jadi set data yang digunakan sebagai pelatihan dengan algoritma adalah himpunan data dari dimensi fitur yang lama $r$ ke dimensi bari $q$. Misalnya untuk contoh data $\mathrm{N}$ sebagai berikut:

$$
\left(\Phi\left(x_{1}\right), y_{1}, \Phi\left(x_{2}\right), y_{2}, \Phi\left(x_{N}\right), y_{N}\right) \in D^{q}
$$

Proses pemetaan pada fase ini memerlukan perhitungan perkalian titik dua buah data pada ruang fitur baru. perkalian titik kedua buah vektor $\left(x_{1}\right)$ dan (xj) dinotasikan sebagai $\Phi\left(x_{1}\right) \Phi(x j)$, Nilai dotproduct kedua buah vektor ini dapat dihitung secara tidak langsung, yaitu tanpa mengetahui fungsi transformasi $\Phi$. Teknik komputasi seperti ini disebut kernel trick, yaitu menghitung dot-product dua buah vektor di ruang dimensi baru dengan memakai komponenkedua buah vektor tersebut di ruang dimensi asal sebagai berikut:

$$
K\left(x i, x_{j}\right)=\Phi\left(x_{i}\right) . \Phi\left(x_{j}\right)
$$

Dan untuk prediksi pada set data dengan dimensi fitur yang baru di formulasikan sebagai berikut:

$$
\mathrm{f}(\Phi(\mathrm{x}))=\operatorname{sign}(w \cdot \Phi(\mathrm{z})+\mathrm{b})=\operatorname{sign}\left(\sum_{i=1}^{N} \alpha_{i} y_{i} \Phi\left(\mathrm{x}_{\mathrm{i}}\right), \Phi(\mathrm{z})+\mathrm{b}\right)(26)
$$

$N$ adalah jumlah data yang menjadi support vector, $x i$ adalah support vector, dan $z$ adalah data uji yang akan dilakukan prediksi.

\section{Metode Penelitian}

Penelitian ini menggunakan GLCM untuk melakukan ekstraksi ciri, dan menggunakan metode support vector machine untuk pelatihan dan pengujian data. Data yang digunakan adalah citra daging kambing, daging kerbau, daging kuda, dan daging sapi yang diambil dengan jarak tinggi dari objek citra sekitar $20 \mathrm{~cm}, 30 \mathrm{~cm}, 40 \mathrm{~cm}$.

\subsection{Prosedur Penelitian}

Prosedur penelitian klasifikasi citra jenis daging berdasarkan tekstur menggunakan ekstraksi ciri GLCM disajikan dalam Gambar 7. di bawah ini:

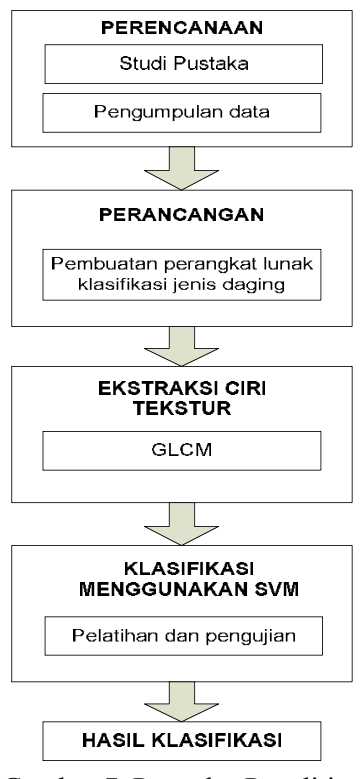

Gambar 7. Prosedur Penelitian

\subsection{Algoritma Klasifikasi Citra}

Algoritma klasifikasi citra jenis daging berdasarkan tekstur menggunakan ekstraksi ciri GLCM disajikan dalam Gambar 8.

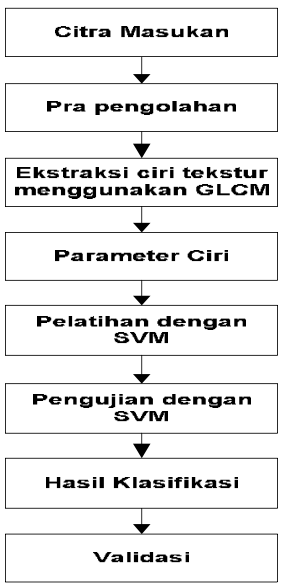

Gambar 8. Algoritma Klasifikasi Citra 


\subsection{Algoritma Prapengolahan}

Prapengolahan dilakukan untuk memperoleh citra skala keabuan. Prapengolahan memiliki serangkaian proses yang ditunjukkan dalam Gambar 9.

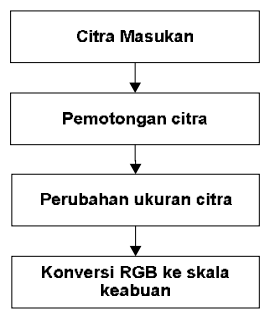

Gambar 9. Algoritma Prapengolahan

\subsection{Algoritma Ekstraksi Ciri Tekstur}

Algoritma ekstraksi ciri tekstur ditunjukkan dalam Gambar 10.

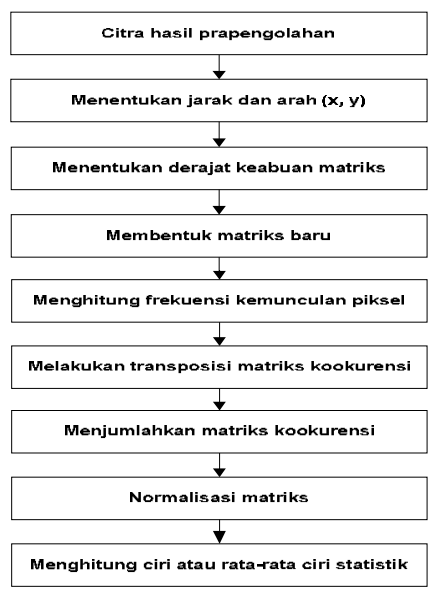

Gambar 10. Algoritma ekstraksi ciri tekstur menggunakan GLCM

\subsection{Kerangka Sistem Informasi}

Kerangka penelitian klasifikasi citra jenis daging berdasarkan tekstur menggunakan ekstraksi ciri GLCM disajikan dalam Gambar 11.

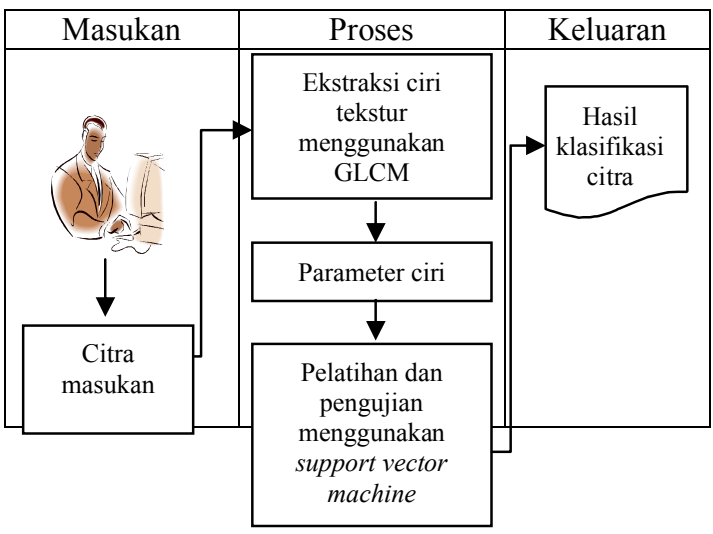

Gambar 11. Kerangka Penelitian

\section{Hasil dan Pembahasan}

Data yang digunakan pada penelitian ini adalah citra daging kambing, kerbau, kuda, dan sapi. Seluruh citra diambil menggunakan kamera digital Nikon D3200 dengan resolusi 24 mega piksel dengan jarak tinggi sekitar $20 \mathrm{~cm}, 30 \mathrm{~cm}$, dan $40 \mathrm{~cm}$ dari objek citra. Jumlah masing-masing citra jenis daging tersebut adalah 150 citra. Dengan demikian, jumlah data citra daging untuk masing-masing jarak pengambilan adalah 600 citra. Sedangkan total keseluruhan citra adalah 1800 citra.

Dalam penelitian ini terdapat beberapa pembahasan yaitu pengaruh jarak piksel tetangga $(\mathrm{d}=1, \mathrm{~d}=2, \mathrm{~d}=3, \mathrm{~d}=4)$ dan arah GLCM terhadap hasil klasifikasi, pengaruh ukuran jarak pengambilan citra $20 \mathrm{~cm}, 30 \mathrm{~cm}$, dan $40 \mathrm{~cm}$ terhadap hasil klasifikasi, pengaruh penggunaan nilai parameter yang berbeda menggunakan kernel RBF terhadap hasil klasifikasi.

4.1. Pengaruh jarak piksel tetangga dan arah GLCM terhadap hasil klasifikasi (citra dengan jarak pengambilan $20 \mathrm{~cm}$ )

Jarak piksel tetangga yang digunakan pada pembahasan ini adalah $\mathrm{d}=1, \mathrm{~d}=2, \mathrm{~d}=3, \mathrm{~d}=4$. Sedangkan arah GLCM yang digunakan adalah empat arah yakni $0^{\circ}, 45^{\circ}, 90^{\circ}, 135^{\circ}$, dan gabungan keempat arah. Parameter sigma kernel RBF yang digunakan adalah 0,4. Citra yang digunakan adalah citra yang diambil dengan jarak $20 \mathrm{~cm}$ dengan jumlah 150 citra untuk masing-masing jenis daging. Total keseluruhan terdapat 600 citra. Jumlah citra yang digunakan sebagai pengujian untuk masingmasing jenis daging adalah 30 citra. Dengan demikian total keseluruhan data yang digunakan untuk pelatihan adalah 480 citra, dan total data untuk pengujian adalah 120 citra. Hasil pembahasan terhadap jarak piksel tetangga ini disajikan dalam Tabel 2.

Tabel 2. Tabel pengaruh jarak piksel tetangga dan arah GLCM dengan jarak pengambilan $20 \mathrm{~cm}$

\begin{tabular}{|c|c|c|c|c|c|c|c|c|c|c|c|}
\hline \multirow{3}{*}{$\begin{array}{c}\text { Jarak } \\
\text { piksel } \\
\text { tetangga }\end{array}$} & \multirow{3}{*}{$\begin{array}{l}\text { Jumlah } \\
\text { data } \\
\text { pengujian }\end{array}$} & \multicolumn{10}{|c|}{ Hasil Klasifikasi \% } \\
\hline & & \multicolumn{2}{|c|}{$0^{\circ}$} & \multicolumn{2}{|c|}{$45^{\circ}$} & \multicolumn{2}{|c|}{$90^{\circ}$} & \multicolumn{2}{|c|}{$135^{\circ}$} & \multicolumn{2}{|c|}{$\begin{array}{c}\text { Gabungan } 4 \\
\text { arah }\end{array}$} \\
\hline & & B & $\mathrm{S}$ & B & S & B & S & B & $\mathrm{S}$ & B & S \\
\hline$d=1$ & 120 & 75,8 & 24,2 & 73,3 & 26,7 & 78,3 & 21,7 & 84,2 & 15,8 & 78,3 & 21,7 \\
\hline$d=2$ & 120 & 69,2 & 30,8 & 73,3 & 26,7 & 75 & 25 & 87,5 & 12,5 & 79,2 & 20,8 \\
\hline$d=3$ & 120 & 70,8 & 29,2 & 73,3 & 26,7 & 75 & 25 & 75 & 25 & 77,5 & 22,5 \\
\hline$d=4$ & 120 & 70 & 30 & 70 & 30 & 78,3 & 21,7 & 82,5 & 17,5 & 76,7 & 23,3 \\
\hline
\end{tabular}

Berdasarkan Tabel 2 terlihat bahwa prosentase hasil klasifikasi dengan nilai error terkecil untuk keseluruhan jarak piksel tetangga berada pada jarak $\mathrm{d}=2$ dengan arah GLCM $135^{\circ}$ yaitu $87,5 \%$ untuk hasil klasifikasi benar dan $12,5 \%$ untuk hasil klasifikasi salah. 
4.2. Pengaruh jarak piksel tetangga dan arah GLCM terhadap hasil klasifikasi (citra dengan jarak pengambilan $30 \mathrm{~cm}$ )

Pada pembahasan ini, citra yang digunakan adalah citra dengan jarak pengambilan $30 \mathrm{~cm}$. Jarak piksel tetangga yang digunakan adalah $\mathrm{d}=1, \mathrm{~d}=2, \mathrm{~d}=3, \mathrm{~d}=4$ dengan $\operatorname{arah}$ GLCM $0^{\circ}, 45^{\circ}, 90^{\circ}$, $135^{\circ}$, dan gabungan keempat arah. Parameter sigma kernel RBF yang digunakan adalah 0,1. Total keseluruhan data adalah 600 citra (masing-masing jening daging 150 citra). Sedangkan total data yang digunakan untuk pengujian adalah 120 citra (masing-masing jenis daging 30 citra). Hasil pembahasan ini disajikan dalam Tabel 3.

Tabel 3. Tabel pengaruh jarak piksel tetangga dan arah GLCM dengan jarak pengambilan $30 \mathrm{~cm}$

\begin{tabular}{|c|c|c|c|c|c|c|c|c|c|c|c|}
\hline \multirow{3}{*}{$\begin{array}{c}\text { Jarak } \\
\text { piksel } \\
\text { tetangga }\end{array}$} & \multirow{3}{*}{$\begin{array}{l}\text { Jumlah } \\
\text { data } \\
\text { pengujian }\end{array}$} & \multicolumn{10}{|c|}{ Hasil Klasifikasi \% } \\
\hline & & \multicolumn{2}{|c|}{$\infty^{\circ}$} & \multicolumn{2}{|c|}{$45^{\circ}$} & \multicolumn{2}{|c|}{$90^{\circ}$} & \multicolumn{2}{|c|}{$135^{\circ}$} & \multicolumn{2}{|c|}{$\begin{array}{c}\text { Gabungan } 4 \\
\text { arah }\end{array}$} \\
\hline & & B & S & B & S & B & S & B & S & B & $\mathrm{s}$ \\
\hline$d=1$ & 120 & 75 & 25 & 72,5 & 27,5 & 81,7 & 18,3 & 73,3 & 26,7 & 73,3 & 26,7 \\
\hline$d=2$ & 120 & 79,2 & 20,8 & 70 & 30 & 83,3 & 16,7 & 70,8 & 29,2 & 71,7 & 28,3 \\
\hline$d=3$ & 120 & 75,8 & 24,2 & 66,7 & 33,3 & 80 & 20 & 75 & 25 & 75,8 & 24,2 \\
\hline $\mathrm{d}=4$ & 120 & 74,2 & 25,8 & 61,7 & 38,3 & 78,3 & 21,7 & 65,8 & 34,2 & 75 & 25 \\
\hline
\end{tabular}

Dari Tabel 3 terlihat bahwa prosentase hasil klasifikasi dengan nilai error terkecil untuk keseluruhan jarak piksel tetangga berada pada jarak $\mathrm{d}=2$ dengan arah GLCM $90^{\circ}$ yaitu $83,3 \%$ untuk hasil klasifikasi benar dan 16,7\% untuk hasil klasifikasi salah.

4.3. Pengaruh jarak piksel tetangga dan arah GLCM terhadap hasil klasifikasi (citra dengan jarak pengambilan $40 \mathrm{~cm}$ )

Citra yang digunakan adalah citra dengan jarak pengambilan $40 \mathrm{~cm}$. Jarak piksel tetangga yang digunakan adalah $\mathrm{d}=1, \mathrm{~d}=2, \mathrm{~d}=3, \mathrm{~d}=4$ dengan arah GLCM $0^{\circ}, 45^{\circ}, 90^{\circ}, 135^{\circ}$, dan gabungan keempat arah. Parameter sigma kernel RBF yang digunakan adalah 0,1. Total keseluruhan data adalah 600 citra. Sedangkan total data yang digunakan untuk pengujian adalah 120 citra. Hasil pembahasan ini disajikan dalam Tabel 4.

Tabel 4. Tabel pengaruh jarak piksel tetangga dan arah GLCM dengan jarak pengambilan $40 \mathrm{~cm}$

\begin{tabular}{|c|c|c|c|c|c|c|c|c|c|c|c|}
\hline \multirow{3}{*}{$\begin{array}{c}\text { Jarak } \\
\text { piksel } \\
\text { tetangga }\end{array}$} & \multirow{3}{*}{$\begin{array}{c}\text { Jumlah } \\
\text { data } \\
\text { pengujian }\end{array}$} & \multicolumn{10}{|c|}{ Hasil Klasifikasi \% } \\
\hline & & \multicolumn{2}{|c|}{$\infty$} & \multicolumn{2}{|c|}{$45^{\circ}$} & \multicolumn{2}{|c|}{$90^{\circ}$} & \multicolumn{2}{|c|}{$135^{\circ}$} & \multicolumn{2}{|c|}{$\begin{array}{c}\text { Gabungan } 4 \\
\text { arah }\end{array}$} \\
\hline & & B & $\mathrm{s}$ & B & S & B & S & B & S & B & $\mathrm{s}$ \\
\hline$d=1$ & 120 & 66,7 & 33,3 & 66,7 & 33,3 & 71,7 & 28,3 & 69,2 & 30,8 & 69,2 & 30,8 \\
\hline$d=2$ & 120 & 70,8 & 29,2 & 69,2 & 30,8 & 80 & 20 & 66,7 & 33,3 & 69,2 & 30,8 \\
\hline$d=3$ & 120 & 65,8 & 34,2 & 70 & 30 & 77,5 & 22,5 & 69,2 & 30,8 & 75 & 25 \\
\hline$d=4$ & 120 & 60 & 40 & 60,8 & 39,2 & 70 & 30 & 67,5 & 32,5 & 73,3 & 26,7 \\
\hline
\end{tabular}

Dari Tabel 4 terlihat bahwa prosentase hasil klasifikasi dengan nilai error terkecil untuk keseluruhan jarak piksel tetangga berada pada jarak $\mathrm{d}=2$ dengan arah GLCM $90^{\circ}$ yaitu $80 \%$ untuk hasil klasifikasi benar dan 20\% untuk hasil klasifikasi salah.

4.4. Pengaruh ukuran pengambilan citra $20 \mathrm{~cm}, 30$ $\mathrm{cm}$, dan $40 \mathrm{~cm}$ terhadap hasil klasifikasi

Pembahasan ini akan membandingkan citra yang diambil dengan jarak $20 \mathrm{~cm}, 30 \mathrm{~cm}$, dan $40 \mathrm{~cm}$. Jarak piksel tetangga yang digunakan adalah $\mathrm{d}=1$ dengan arah GLCM $0^{\circ}, 45^{\circ}, 90^{\circ}, 135^{\circ}$, dan gabungan keempat arah. Parameter sigma kernel RBF yang digunakan adalah 0,3. Total keseluruhan terdapat 600 citra. Jumlah citra yang digunakan sebagai pengujian adalah 120 citra. Hasil pembahasan ini disajikan dalam Tabel 5.

Tabel 5. Tabel ukuran jarak pengambilan citra $20 \mathrm{~cm}, 30$ $\mathrm{cm}$, dan $40 \mathrm{~cm}$ terhadap hasil klasifikasi.

\begin{tabular}{|c|c|c|c|c|c|c|c|c|c|c|c|}
\hline \multirow{4}{*}{$\begin{array}{c}\text { Jarak } \\
\text { pengambilan } \\
\text { citra }\end{array}$} & \multirow{4}{*}{$\begin{array}{l}\text { Jumlah } \\
\text { data } \\
\text { pengujian }\end{array}$} & \multicolumn{10}{|c|}{ Hasil Klasifikasi \% } \\
\hline & & \multicolumn{10}{|c|}{ Jarak piksel tetangga $d=1$} \\
\hline & & \multicolumn{2}{|c|}{$\infty^{\infty}-1+3-1+1$} & \multicolumn{2}{|c|}{$45^{\circ}$} & \multicolumn{2}{|c|}{$90^{\circ}$} & \multicolumn{2}{|c|}{$135^{\circ}$} & \multicolumn{2}{|c|}{$\begin{array}{c}\text { Gabungan } 4 \\
\text { arah }\end{array}$} \\
\hline & & B & $\mathrm{s}$ & B & $\mathrm{s}$ & B & $\mathrm{s}$ & B & $\mathrm{s}$ & B & $\mathrm{s}$ \\
\hline $20 \mathrm{~cm}$ & 120 & 74,2 & 25,8 & 70 & 30 & 78,3 & 21,7 & 85,8 & 14,2 & 76,7 & 23,3 \\
\hline $30 \mathrm{~cm}$ & 120 & 70 & 30 & 72,5 & 27,5 & 75 & 25 & 69,2 & 30,8 & 71,7 & 28,3 \\
\hline $40 \mathrm{~cm}$ & 120 & 63,3 & 36,7 & 66,7 & 33,3 & 65 & 35 & 66,7 & 33,3 & 60 & 40 \\
\hline
\end{tabular}

Pada Tabel 5 terlihat bahwa prosentase dengan nilai error terkecil terletak pada jarak pengambilan $20 \mathrm{~cm}$ pada arah GLCM $135^{\circ}$ yaitu sebesar $85,8 \%$ untuk hasil klasifikasi benar dan 14,2\% untuk hasil klasifikasi salah.

4.6. Pengaruh penggunaan nilai parameter yang berbeda terhadap hasil klasifikasi

Pada Tabel 5 jika jarak pengambilan citra $20 \mathrm{~cm}$ dengan jarak piksel tetangga $\mathrm{d}=1$ pada arah GLCM $135^{\circ}$ menggunakan parameter sigma kernel RBF 0,1 sampai dengan 6,0, maka hasil pengujian dapat dilihat pada Gambar 12.

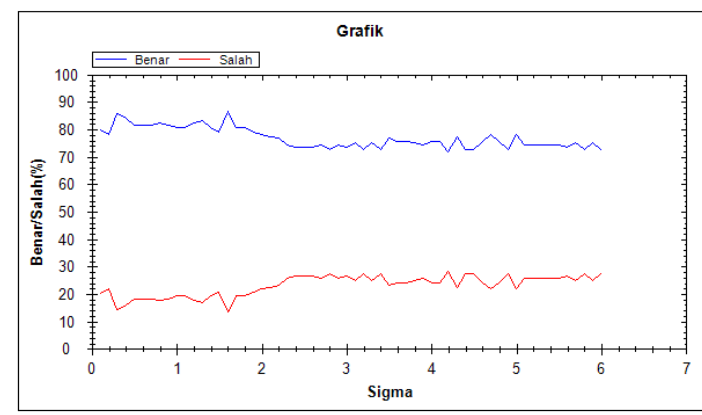

Gambar 12. Grafik hasil klasifikasi dengan jarak pengambilan $20 \mathrm{~cm}$

Dari Gambar 12 terlihat bahwa dengan menggunakan parameter sigma yang berbeda-beda, 
nilai error terkecil untuk hasil klasifikasi adalah $14,2 \%$ yakni pada parameter sigma 0,3 .

Jika jarak pengambilan citra $30 \mathrm{~cm}$ dengan jarak piksel tetangga $\mathrm{d}=1$ pada arah GLCM $135^{\circ}$ pada tabel 4.4 menggunakan parameter sigma kernel RBF 0,1 sampai dengan 6,0 , maka hasil pengujian dapat dilihat pada Gambar 13 .

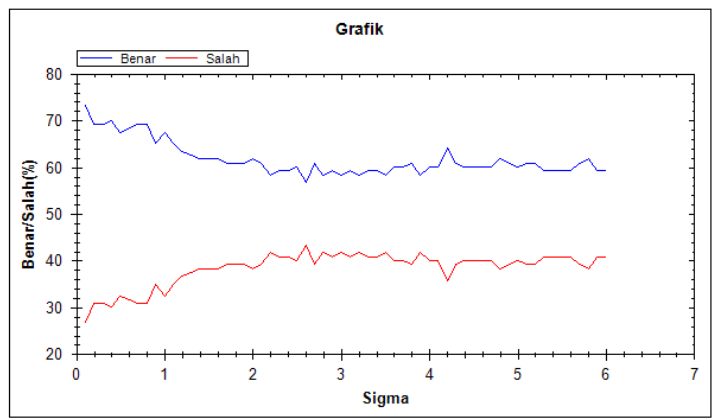

Gambar 13 Grafik hasil klasifikasi dengan jarak pengambilan $30 \mathrm{~cm}$

Dari Gambar 13 terlihat bahwa dengan menggunakan parameter sigma 0,1 sampai dengan 6,0 , nilai error terkecil untuk hasil klasifikasi adalah $26,7 \%$ yakni pada parameter sigma 0,1 .

Jika jarak pengambilan citra $40 \mathrm{~cm}$ dengan jarak piksel tetangga $\mathrm{d}=1$ pada arah GLCM $135^{\circ}$ pada tabel 4.4 menggunakan parameter sigma kernel RBF 0,1 sampai dengan 6,0 , maka hasil pengujian dapat dilihat pada Gambar 14

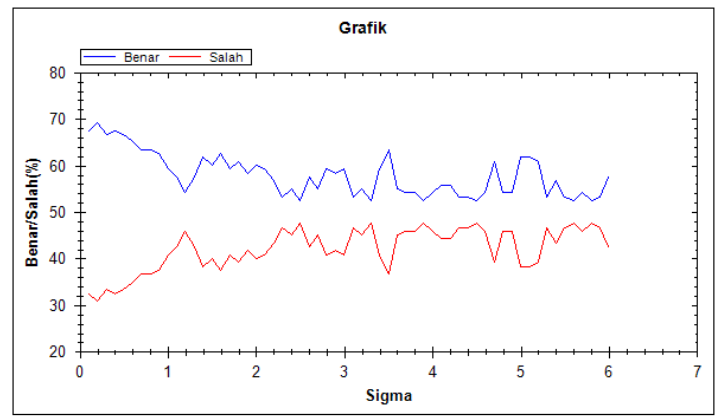

Gambar 14. Grafik hasil klasifikasi dengan jarak pengambilan $40 \mathrm{~cm}$

Dari Gambar 14 terlihat bahwa dengan menggunakan parameter sigma yang berbeda-beda, nilai error terkecil untuk hasil klasifikasi adalah $30,8 \%$ yakni pada parameter sigma 0,2 .

\section{Kesimpulan}

Dari hasil penelitian ini, dapat diambil kesimpulan bahwa:

1. Sistem pengenalan daging yang dikembangkan, memiliki tingkat pengenalan terbaik $87,5 \%$ yang terjadi pada citra dengan jarak pengambilan 20 $\mathrm{cm}$ dengan kondisi jarak piksel tetangga $\mathrm{d}=2$ pada arah GLCM $135^{\circ}$. Tingkat pengenalan tersebut berada pada parameter sigma 0,4 .

2. Citra dengan ukuran jarak pengambilan $20 \mathrm{~cm}$ memiliki nilai error paling kecil yakni $14,2 \%$ dibandingkan dengan citra yang diambil dengan jarak $30 \mathrm{~cm}$ ataupun $40 \mathrm{~cm}$. Nilai error tersebut berada pada jarak piksel tetangga $\mathrm{d}=1$ dengan arah GLCM $135^{\circ}$.

3. Penggunaan nilai parameter sigma kernel RBF 0,1 sampai dengan 6,0 untuk masing-masing citra dengan jarak pengambilan $20 \mathrm{~cm}, 30 \mathrm{~cm}$, dan $40 \mathrm{~cm}$, menghasilkan klasifikasi dengan nilai error terkecil yakni 14,2\%. Error terkecil tersebut berada pada citra dengan jarak pengambilan $20 \mathrm{~cm}$ dengan jarak piksel tetangga $\mathrm{d}=1$ pada arah GLCM $135^{\circ}$.

4. Berdasarkan berbagai pengujian yang telah dilakukan, citra dengan ukuran jarak pengambilan $20 \mathrm{~cm}$ memiliki tingkat pengenalan terbaik dibandingkan dengan citra yang diambil dengan jarak $30 \mathrm{~cm}$ ataupun 40 $\mathrm{cm}$. Dengan demikian, citra dengan ukuran jarak pengambilan $20 \mathrm{~cm}$ dapat direkomendasikan untuk klasifikasi citra jenis daging.

\section{Daftar Pustaka}

Basset, O., Buquet, B., Abouelkaram, S., Delachartre, P., dan Culioli, J., 2000. Application of texture image analysis for the classification of bovine meat. Food Chemistry, 69, 437-445.

Bharati, M. H., Liu, J. J. and Mac Gregor, J. F., 2004. Image texture analysis: methods and comparisons. Chemometrics and Intelligence Laboratory Systems, 72, 57-71.

Burges, C.J., 1998. A Tutorial on support vector machines for pattern recognition. Data Mining and Knowledge Discovery, 2, 1-43.

Haralick, R.M., 1979. Statistical and structural approaches to texture. Proceedings of the IEEE, 67, 786-804.

Haralick, R.M., Shanmugam, K., dan Dinstein, I., 1973. Textural features for image classification. IEEE Transactions on Systems, Man, and Cybernetics, 6, 610-621.

Kadir, A., dan Susanto, A., 2012. Teori dan aplikasi pengolahan citra, Andi: Yogyakarta.

Kadir, A. dan Susanto, A., 2013. Teori dan Aplikasi Pengolahan Citra, Andi: Yogyakarta.

Kudo, M. and Sklansky. J., 2000. Comparison of algorithms that select features for pattern classifiers. Pattern Recognition, 33, 25-41.

Krutz, G.W., Gibson, H.G., Cassens, D.L. and Zhang, M., 2000. Colour vision in forest and wood engineering. Landwards, 55, 2-9.

Nello, C., dan Taylor, J.S., 2000. An introduction to support vector machines and other kernel- 
based learning methods, Cambridge University Press.

Patel, D., Davies, E.R. and Hannah, I, 1996. The use of convolution operators for detecting contaminants in food images. Pattern Recognition, 29 (6), 1019-1030.

Prasetyo, E., 2012. Data Mining Konsep dan Aplikasi Menggunkan Matlab, Andi: Yogyakarta.

Prasetyo, E., 2014. Data Mining Mengolah Data Menjadi Informasi Menggunakan Matlab. Andi Publisher: Yogyakarta.

Salat, R. dan Osowski, S., 2004. Accurate fault location in the power transmission line using support vector machine approach, IEEE Trans. Power Syst., 19, 879-886.

Seetha, M., Muralikrishna, I.V., Deekshatulu, B.L., Malleswari, B.L., Nagaratna, Hedge, P., 2008. Artificial neural network and other methods of image classification. Journal of Theoretical and Applied Information Technology, 1039-1053.
Schwartz. W, Pedrini. H, 2006. Textured image segmentation based on spatial dependence usinga Markov random field model, IEEE International Conference on Image Processing, Atlanta, GA, USA, pp. 2449-2452.

Sun, D-W., 2000. Inspecting pizza topping percentage and distribution by a computer vision method. Journal of Food Engineering, 44, 245-249.

Siqueira, F.R.D., Schwartz, W.R., Pedrini, H., 2013. Multi-scale gray level co-occurrence matrices for texture description. Neurocomputing, 120, 336-345.

Zheng, C., Sun, D-W., dan Zheng, L., 2006. Recent applications of image texture for evaluation of food qualities - a review. Trends in Food Science \& Technology, 17, 113-128. 